\title{
sciendo
}

DOI 10.2478/afepuc-2020-0011

(C) Acta Facultatis Educationis Physicae Universitatis Comenianae 2020, 60(2): 133-145

\section{DEVELOPMENT OF HOCKEY GAME AND MODEL FOR LEARNING PHYSICAL EDUCATION IN CHILDREN'S ELEMENTARY SCHOOL}

\author{
Nuzulla Saputri, Suharjana \\ ${ }^{I}$ Sports Science Postgraduates Program Universitas Negeri Yogyakarta INDONESIA \\ ${ }^{2}$ Sports Science of Faculty Universitas Negeri Yogyakarta INDONESIA
}

\begin{abstract}
Summary: The purpose of this study is to develop tools and products for the hockey water pipe (PSA) game model in order to overcome the problem of limited facilities and infrastructure and improve students' movement coordination skills and increase the variety of small ball games. This research is a research and development $(\mathrm{RnD})$ that refers to Sugiyono's (2013) theory which is product oriented. The results of this study have been found (1) the Hockey PSA game model can attract the attention of upper elementary school students to get to know the Hockey game (2) The Hockey PSA game model can add variety to the game for teachers who teach upper grade elementary school children (3) the game model PSA Hoki can express the imagination of upper elementary school students in the combination of modification of tools and games with the results of the affective aspects of the trial that is the aspect of students willing to play again obtained a percentage of $92.08 \%$ (very feasible). The conclusion of this research is the Hockey PSA game model can overcome the problem of limited facilities and infrastructure improve student movement coordination and increase the variety of small ball game material.
\end{abstract}

Keywords: modifications, hockey, games, physical education, learning, elementary school

\section{Introduction}

The little ball game is one of the subject matter that exists in the elementary school physical education learning process (Burhaein 2017b; Mustofa Mansur \& Burhaein 2019). Based on the information and provisions in the references used in the 2013 curriculum in the Basic Competence (KD) section a physical education teacher at a high school can be individually developing their creativity in the learning process (Kemendikbud RI 2013). Creativity can be through games that refer to the concept of motion in games that use small ball media (Burhaein 2017a; Purnomo Tomoliyus \& Burhaein 2019). The theory of motion in games 
carried out in physical education learning includes variations and combinations of basic motion patterns namely locomotor motion non-locomotor motion and manipulative motion.

Small ball game is a game which in its implementation uses a small ball. In addition to small balls most small ball games use tools to support them (Ardian Suharjana \& Burhaein 2019; H. Hakim 2013). There are many kinds of small ball games including baseball rounders kippers roasted balls (Mustofa et al. 2019; Sintara \& Sonchan 2015). One type of small ball game that is almost never taught in the physical education learning materials of upper class elementary schools is Hockey.

Hockey is one type of small ball game. Hockey is a game that is played between two teams each team using a crooked stick or stick to move the ball (Kaur 2018; Phytanza Burhaein Sukoco \& Ghautama 2018). The goal of the Hockey game is to put the ball as much as possible into the opponent's goal and keep the goal in order not to concede the ball.

Researchers conducted observations and observations at elementary school (SD) Muhammadiyah Kregan Cangkringan. The introduction of the Hockey game was done to elementary school children but it did not continue due to damaged infrastructure and the modification of the hockey game model so elementary school children did not have any knowledge of the Hockey game. In addition limited facilities are the main cause of the introduction of Hockey material when learning upper-class physical education in elementary schools. In this regard the implementation of the game of Hockey sticks will become a very important part in the implementation of learning activities both Hockey sticks that are in accordance with the standards or modified Hockey sticks (Jerath \& Long 2020; Pramantik \& Burhaein 2019). Based on the identification results not all elementary schools in Sleman have a number of Hockey sticks which are adequate for implementing Hockey game learning.

Modification is an attempt to make the game of Hockey easier and more interesting to be played by students (A. Hakim Ambardini Nugroho \& Burhaein 2018; Wibawa 2017). In addition modification is expected to change the notion that Hockey is dangerous and does not need to be taught in elementary school physical education. In field hockey the number of players is twenty-two (22) for 2 teams with a composition of 20 players and 2 goalkeepers then the size of the field used is 91.40 meters long and 55 meters wide (Ciavarro Dobson \& Goodman 2008; Phytanza \& Burhaein 2019). Researchers conducted interviews with a number of hockey game equipment traders and obtained the results of playing field hockey using a ball at a price of $\mathrm{Rp}$. 200000 - and sticky wood (stick) the purchase price of each stick (stick) reaches Rp. 1000000 per stick and body protector for the goalkeeper whose prices reach tens of millions. This is one 
of the reasons behind the lack of introduction of the game of Hockey for elementary school children.

With games that are packaged creatively it will be fun for upper class students to play the game of Hockey and save on the costs needed. Furthermore physical activity can benefit the child and the child is better prepared to continue the next meeting with more complex material. For this reason the form of hockey game activities needs to be developed to meet students' needs for movement and which will support the process of growth and development as well.

\section{Methods}

\section{Participant}

The participants of this study were students of grade 6 SD Muhammadiyah Kergan in Cangkringan sub-district in Indonesia. The number of participants with a total of 25 students 13 boys and 12 girls with ages $12-14(\mathrm{M}=13.5 ; \mathrm{SD}=1.49)$.

\section{Research methods}

This research is a type of development research (Research and Development). Steps for Using the Research and Development (R\&D) Methods according to Sugiyono (Sugiyono 2014) are: 1 . finding the potential problems; 2 . data collection; 3 . product design; 4 . validity; 5 . design revision; 6. product trials; 7. product revisions; 8. product trials; 9. product revisions; 10. mass product/ yield.

\section{Instrument and Data collection technique}

The instrument used in this study was the product of the validity of the material expert. The validity of the product is obtained from the results of filling out the questionnaire and evaluation sheet given to the validator. The questionnaire was based on the assessment needs. The type of data used in this study is quantitative and qualitative data. Quantitative data are scores obtained from questionnaires filled in by material experts media experts and students. While the qualitative data obtained from the results of the conversion of scores of quantitative data obtained by the assessment determining the quality of the game model.

\section{Data analysis}

Data analysis techniques are the ways how to find out the results of research conducted. Data analysis includes all the activities of clarifying, analyzing, using and drawing conclusions from all data collected in action. After the data is collected, the data will be processed. The data analysis technique used in this study is a quantitative analysis technique that is assessment using 
numbers.

Percentage is intended to find out the status of something that is presented and presented as a percentage. The calculation formula for eligibility according to Sugiyono (Sugiyono 2014) is as follows:

$$
\text { Formula: } \frac{S H}{S K} \times 100 \%
$$

Information:

SH: Calculate Score

SK: Criterium Score or Ideal Score

The results of subsequent data calculations are made in the form of a percentage multiplied by $100 \%$. The results of the percentage obtained with the formula then include the feasibility of a hockey game model for physical education learning for upper grade elementary school children in this development research which is classified into five categories of eligibility that are not feasible, less feasible, decent enough, decent and very feasible.

\section{Result}

\section{Material Expert Validation Data}

Material experts who become validators in this research development are Dra. Sri Mawarti M.Pd. namely an expert lecturer in the field of hockey sports Faculty of Sports Science Yogyakarta State University. Researchers chose him as a material expert because his competence in the field of hockey games was very adequate. Material expert data retrieval was carried out in April 2017 obtained by providing initial media products and the book "Game Model of Hockey" along with assessment sheets in the form of questionnaires.

1) Suggestion

The validator gives advice in the revised section column "no. 11 which is meant for what kind of skilled?"

2) Comments

The general comments and suggestions column the validator as a material expert gives input to the hockey game product model that is "tools facilities and infrastructure can be used for fourth grade elementary school students in addition to game subjects".

Table 1

Data from Expert Material Evaluation Results 


\begin{tabular}{|c|c|c|c|c|c|}
\hline No. & $\begin{array}{c}\text { Rated } \\
\text { aspect }\end{array}$ & $\begin{array}{c}\text { Score } \\
\text { Obtained }\end{array}$ & $\begin{array}{c}\text { Maximum } \\
\text { Score }\end{array}$ & $\begin{array}{c}\text { Percentage } \\
(\mathbf{\%})\end{array}$ & Category \\
\hline 1. & Theory & 61 & 75 & $81 \%$ & $\begin{array}{c}\text { Very } \\
\text { decent }\end{array}$ \\
\hline \multicolumn{2}{|c|}{ Total Score } & 61 & 75 & $81 \%$ & $\begin{array}{c}\text { Very } \\
\text { decent }\end{array}$ \\
\hline
\end{tabular}

Source: Primary data processing for 2017

In the validation of the percentage obtained $81 \%$ thus it can be stated that according to the material expert at the stage of validation of the hockey game material that was developed from the aspect of the feasibility of the contents of the material get the category "Very Eligible".

\section{Validation of Infrastructure (Sarpras) Expert}

Infrastructure expert who became the validator in this research development was Dra. A.Erlina Listyarini M.Pd. He is an expert lecturer in sports facilities and infrastructure Faculty of Sports Science Yogyakarta State University. Researchers chose him as a material expert because of his competence in the field of facilities and infrastructure especially for playing hockey which was very adequate.

Material expert data retrieval was carried out in April 2017 obtained by providing initial media products and the book "Game Model of Hockey" along with assessment sheets in the form of questionnaires.

1) Suggestion

The validator provides advice in the revised section column "game rules (number of players) improved"

2) Comments

The general comments and suggestions column the validator as the material expert gives input to the hockey game product model namely "If the researcher still determines the number of participants the title must be changed but if it matches the title above then the number of players (participants) is replaced with the number of students there are. divided into 2 (two) teams (because of learning)".

In the validation of the percentage obtained $81 \%$ it can be stated that according to the expert on facilities and infrastructure at the stage of validation of the facilities and infrastructure of hockey games developed from aspects of the feasibility of facilities and infrastructure get the category "Very Eligible".

\section{Table 2}

Data from Sarpras Expert Assessment Results 


\begin{tabular}{|c|c|c|c|c|c|}
\hline No. & Rated aspect & $\begin{array}{c}\text { Score } \\
\text { Obtained }\end{array}$ & $\begin{array}{c}\text { Maximum } \\
\text { Score }\end{array}$ & $\begin{array}{c}\text { Percentage } \\
(\mathbf{\%})\end{array}$ & Category \\
\hline 1. & Sarpras & 61 & 75 & $81 \%$ & Very decent \\
\hline \multicolumn{2}{|c|}{ Total Score } & 61 & 75 & $81 \%$ & Very decent \\
\hline
\end{tabular}

Source: Primary data processing for 2017

\section{Data on Validation of Physical Education Learning Experts}

Physical education learning expert who is a validator in this research development is Ahmad Rithaudin M.Or. he is an expert lecturer in the field of learning Faculty of Sports Science Yogyakarta State University. Researchers chose him as a physical education learning because his competence in the field of facilities and infrastructure especially for hockey games was very adequate.

Data collection on physical education learning experts was carried out in April 2017 obtained by providing an initial media product and a "hockey game model" book along with an assessment sheet in the form of a questionnaire or questionnaire.

1) Suggestion

The validator provides advice in the revised section column "rules for using the tool?"

2) Comments

The general comments and suggestions column the validator as the material expert gives input to the hockey game product model that is "Although the rules for using equipment are not included in the rules but when practicing it is necessary to emphasize that in the game actually only one side is allowed to hit the ball".

\section{Physical Education Expert Validation Data Validation}

In the validation of the percentage obtained $86 \%$ thus it can be stated that according to the learning expert at the validation stage the physical education learning activities of hockey games developed from aspects of the feasibility of physical education learning get the category "Very Eligible".

\section{Table 3}

Data on Assessment of Physical Education Experts Assessment

\begin{tabular}{|c|c|c|c|c|c|}
\hline No. & Rated aspect & $\begin{array}{c}\text { Score } \\
\text { Obtained }\end{array}$ & $\begin{array}{c}\text { Maximum } \\
\text { Score }\end{array}$ & $\begin{array}{c}\text { Percentage } \\
(\mathbf{\%})\end{array}$ & Category \\
\hline 1. & Learning & 65 & 75 & $86 \%$ & Very decent \\
\hline \multicolumn{2}{|c|}{ Total Score } & 65 & 75 & $86 \%$ & Very decent \\
\hline
\end{tabular}

Source: Primary data processing for 2017 
In the validation of the percentage obtained $86 \%$ thus it can be stated that according to the learning expert at the validation stage the physical education learning activities of hockey games developed from aspects of the feasibility of physical education learning get the category "Very Eligible".

\section{Validation of Physical Education Practitioners}

Physical education learning expert who is a validator in this research development is Alfia Safitri S.Pd. She is a physical education teacher at Muhammadiyah Kregan Cangkringan Elementary School. Researchers chose him as a physical education practitioner because he was a physical education teacher who would later use research products in the learning process.

Data collection on physical education learning experts was carried out in April 2017 obtained by providing an initial media product and a "hockey game model" book along with an assessment sheet in the form of a questionnaire.

1) Suggestion

The validator as a physical education practitioner does not give advice in the revised section column.

2) Comments

The general comments and suggestions column the validator as a physical education practitioner does not provide general comments and suggestions in the column. The validator gives a conclusion that this model is "feasible for use / small-scale trials without revision".

Table 4

Data on Physical Education Practitioner Assessment Results

\begin{tabular}{|l|l|c|c|c|c|}
\hline No. & Rated aspect & $\begin{array}{c}\text { Score } \\
\text { Obtained }\end{array}$ & $\begin{array}{c}\text { Maximum } \\
\text { Score }\end{array}$ & $\begin{array}{c}\text { Percentage } \\
\mathbf{( \% )}\end{array}$ & Category \\
\hline 1. & Learning & 65 & 75 & $86 \%$ & Very decent \\
\hline \multicolumn{2}{|l|}{ Total Score } & 65 & 75 & $86 \%$ & Very decent \\
\hline
\end{tabular}

Source: Primary data processing for 2017

In the validation of the percentage obtained $86 \%$ thus it can be stated that according to physical education practitioners at the validation stage of physical education learning activities hockey games developed from aspects of physical education learning eligibility get the category "Very decent".

\section{Testing of elementary students (small group trials)}


Table 5

Results Data on Students or Respondents

\begin{tabular}{|c|c|c|c|c|c|}
\hline No. & Rated aspect & $\begin{array}{c}\text { Score } \\
\text { Obtained }\end{array}$ & $\begin{array}{c}\text { Maximum } \\
\text { Score }\end{array}$ & $\begin{array}{c}\text { Percentage } \\
(\mathbf{\%})\end{array}$ & Category \\
\hline 1. & Psychomotor & 224 & 240 & 93.33 & Very decent \\
\hline 2. & Cognitive & 210 & 240 & 87.50 & Very decent \\
\hline 3. & Affective & 221 & 240 & 92.08 & Very decent \\
\hline \multicolumn{2}{|c|}{ Total Score } & 655 & 720 & 90.97 & Very decent \\
\hline
\end{tabular}

Source: Primary data processing for 2017

The results of the questionnaire of elementary school students at an early age regarding hockey game media showed that for the assessment of psychomotor aspects $93.33 \%$ were categorized as "Very Eligible" cognitive aspects were $87.50 \%$ categorized as "Very Eligible" and affective aspects amounted to $92.08 \%$ which were categorized " Very Worthy

". The total assessment of the feasibility test of the hockey game training model according to high school elementary school student respondents was $90.97 \%$ categorized as "Very Eligible" which means that the model was very feasible to use so it did not need to proceed to large group trials.

\section{Discussion}

The research and development of this hockey game was designed and produced into an initial product in the form of learning activities of game materials on physical education subjects for upper elementary school children. Researchers develop this by presenting a hockey game model with a glimpse of the material and rules of the game. The process of developing this model through research and development procedures in several stages of planning production and evaluation. Then the product is developed by looking at the literature relating to game systems and hockey equipment modified using water pipes so that a new hockey game model is produced. The product goes through the next stage to be evaluated to experts through expert validation.

After the expert validation then the product needs to be tested on the participants of the upper class elementary school children. In the evaluation phase material experts facilities and infrastructure specialists physical education learning experts and physical education practitioners. The research phase was carried out by small group trials in this study as many as 24 students to test the final feasibility of the hockey game model developed by researchers. 
This hockey game model is included in the "Very Eligible" criteria. This statement can be proven from the results of the "Very Eligible" assessment analysis from four experts including material experts, facilities and infrastructure experts, physical education learning experts and physical education practitioners. The results of the small group trial evaluation give the conclusion that the total data falls under the "Very Eligible" criteria. High school elementary students feel happy and enthusiastic about this product because high school elementary students are interested in learning and hope that this product can be disseminated to other high school elementary students.

The teacher and several parents of upper elementary school students welcomed the hockey game model. According to them the strengths of the game models are that they are still a new game for children, a unique game tool, a modified game system adapted for learning so that it makes primary school students interested and then has an impact on hockey game products as playing support to attract the attention of high school elementary students. The visual advantage with a bat from a modified water pipe and goalpost makes hockey games interesting and is loved by high-grade elementary school children (Jerath \& Long 2020; Mustofa et al. 2019). High school students' interest in media Hockey games are motivations that can increase student interest during the play process related to increased student movement activities. This product also allows high school elementary students to provide a cognitive understanding of the basic game of hockey. This product is intended for upper elementary school students so they can play actively and independently because this product is easy to use because basically it has been technically modified for elementary school age children.

With the advantages of this product as for the weaknesses in this product include students who are comfortable playing using games without additional tools such as soccer and volleyball then need some time to adapt using sticks as a hockey ball beater. A small portion of students show difficulties at the beginning of learning then start smoothly during learning. Some of these weaknesses are expected to receive attention and further development efforts to obtain better product results. This fact will increasingly open up opportunities for further holding of further research with different aspects.

The test results can be described in the following discussion:

\section{Testing of material experts}

The results of the validation test through a questionnaire to material experts showed a level of relevance to the material level of $81 \%$. The results of the validation mean that 
the material in the hockey game model is very suitable for use in physical education learning in the field.

\section{Testing of facilities and infrastructure experts}

The results of the validation test through a questionnaire to the facilities and infrastructure experts the level of relevance to the material level was $81 \%$. The results of the validation mean that the supporting infrastructure in the hockey game model is very suitable for use in physical education learning in the field.

\section{Testing of physical education learning experts}

Validation test results through a questionnaire to physical education learning the level of relevance into the learning level of $86 \%$. The results of the validation mean that the supporting infrastructure in the hockey game model is very suitable for use in physical education learning in the field.

\section{Testing of physical education practitioners}

The results of the validation test through a questionnaire to physical education practitioners the level of relevance into the category of $86 \%$. The results of the validation mean that the concept of the practice of movement activities in the hockey game model is very suitable for use in learning physical education in the field.

\section{Testing for elementary students (Small group trials)}

The results of the questionnaire of elementary school students at an early age regarding hockey game media showed that for the assessment of psychomotor aspects 93.33 $\%$ were categorized as "Very Eligible" cognitive aspects were $87.50 \%$ categorized as "Very Eligible" and affective aspects amounted to $92.08 \%$ which were categorized " Very Worthy

". The total assessment of the feasibility test of the hockey game training model according to high school elementary school student respondents was $90.97 \%$ categorized as "Very Eligible" which means that the model was very feasible to use so it did not need to proceed to large group trials.

\section{Conclussion}

The results of the research into media development of the hockey game model are categorized as very appropriate to be used as learning media to provide an understanding of the game of hockey for elementary school children. This can be seen from the results of the assessment of material experts $81.00 \%$ Infrastructure Specialists $81.00 \%$ Physical Education 
Specialist $86 \%$ Physical Education Practitioners 86\% and based on the results of field trials of $90.97 \%$.

The contributions of this study are: 1) For Physical Education teachers who support elementary school children in order to be able to utilize and apply this hockey game model as a variation in the delivery of material to attract and motivate high school students; 2) For schools where upper elementary school children learn in order to be able to use hockey games as an educational medium in introducing hockey sports; and 3) For upper elementary school students to be more motivated in playing and observing how to play this hockey game material. Suggestions for further research are expected to develop media models for hockey games more interesting and effective in learning and physical activity based on the shortcomings of this study.

\section{Acknowledgment}

The author would like to thank profusely to all participants and parties involved in this research.

\section{Conflict of Interest}

The author states there is no conflict of interests.

\section{References}

1. ARDIAN, R. SUHARJANA, S. \& BURHAEIN, E., 2019. Effect of progressive and repetitive part methods against the accuracy of kicking in football extracurricular students. ScienceRise. 1(7) 40-44. https://doi.org/10.15587/2313-8416.2019.174318.

2. BURHAEIN, E., 2017a. Aktivitas Fisik Olahraga untuk Pertumbuhan dan Perkembangan Siswa SD. Indonesian Journal of Primary Education. 1(1) 51-58. https://doi.org/10.17509/ijpe.v1i1.7497.

3. BURHAEIN, E., 2017b. Aktivitas Permainan Tradisional Berbasis Neurosainslearning Sebagai Pendidikan Karakter Bagi Anak Tunalaras. Jurnal SPORTIF : Jurnal Penelitian Pembelajaran.3(1) 55. https://doi.org/10.29407/js_unpgri.v3i1.580.

4. CIAVARRO, C., M. DOBSON \& D. GOODMAN, 2008. Computers in Human Behavior Implicit learning as a design strategy for learning games : Alert Hockey. Computers in Human Behavior. 24(6) 2862-2872. https://doi.org/10.1016/j.chb.2008.04.011.

5. HAKIM, A., R. AMBARDINI, W. NUGROHO \& E. BURHAEIN, 2018. Dragon Fruit Giving Effect Against Malondealdehide (MDA) Levels in Muay Tha1 Athletes With High 
Intensity Interval Trainıng (HIIT) Method. Journal of Education Health and Sport. 8(10) 190-198. https://doi.org/10.5281/zenodo.1472727.

6. HAKIM, H., 2013. Analisis Guru Pendidikan Jasmani SD Negeri di Kabupaten Pinrang. Jurnal Ilmu Keolahragaan. 6(2).

7. JERATH, K. \& F. LONG, 2020. Multiperiod Contracting and Salesperson Effort Profiles: The Optimality of “ Hockey Stick” “ Giving Up ” and “ Resting on Laurels .” Journal of Marketing Research. 57(2), 1-25. https://doi.org/10.1177/0022243719887378.

8. KAUR, N., 2018. Assessment of hockey skill accuracy between male and female hockey players. International Journal of Yogic Human Movement and Sports Sciences. 3(1) 387390. Retrieved from http://www.theyogicjournal.com/pdf/2018/vol3issue1/PartG/3-1-15145.pdf.

9. KEMENDIKBUD, RI., 2013. Dokumen kurikulum 2013.

10. MUSTOFA, F., M. MANSUR \& E. BURHAEIN, 2019. Differences in the effect of learning methods massed practice throwing and distributed distributed practice on learning outcomes skills for the accuracy of top softball. Journal of Sport Sciences Researches. 4(2) 213-222. https://doi.org/10.25307/jssr.571793.

11. PHYTANZA, D. T. P. \& E. BURHAEIN, 2019. Aquatic activities as play therapy children autism spectrum disorder. International Journal of Disabilities Sports and Health Sciences. 2(2) 64-71. https://doi.org/10.33438/ijdshs.652086.

12. PHYTANZA, D. T. P., E. BURHAEIN, S. SUKOCO \& S. W. GHAUTAMA, 2018. Life Skill Dimension based on Unified Sports Soccer Program in Physical Education of Intellectual Disability. Yaşam Becerileri Psikoloji Dergisi. 2(4) 199-205. https://doi.org/https://doi.org/10.31461/ybpd.453865.

13. PRAMANTIK, I. A. D. \& E. BURHAEIN, 2019. Disabilities Sports \& Health Science A Floor Time Approach to Improve Learning Outcomes of the Body Roll to the Side in Adaptive Physical Education Learning : Classroom Action Research Study on Two Cerebral Palsy Students. International Journal of Disabilities Sports and Health Sciences. 2(2) $45-$ 53. https://doi.org/10.33438/ijdshs.652061.

14. PURNOMO, I. D., T. TOMOLIYUS \& E. BURHAEIN, 2019. Development of Learning Activities Playing a Ball on a Goal To Improve Manipulative Skills For Lower Class Students. Proceedings of the 1st International Conference on Science and Technology for an Internet of Things. https://doi.org/10.4108/eai.19-10-2018.2281716. 
15. SINTARA, K. \& N. SONCHAN, 2015. Physical fitness of collegiate softball players Burapha University Thailand. Proceedings of the Burapha University International Conference (July) 10-12. Retrieved from:

https://www.researchgate.net/profile/Kawiya_Sintara/publication/280005646_Physical_Fi tness_of_Collegiate_Softball_Players_Burapha_University_Thailand/links/55a3383008ae a815dffd389a/Physical-Fitness-of-Collegiate-Softball-Players-Burapha-UniversityThailan.

16. SUGIYONO, S., 2014. Metode penelitian kuantitatif kualitatif dan R\&D. Bandung: Alfabeta.

17. WIBAWA, Y. E., 2017. Analisis Masa Akhir Kerja Guru Penjasorkes Terhadap Pencapaian Kompetensi Guru Se-MGMP Kabupaten Sleman Korwil Tengah. Jurnal Pendidikan Jasmani Dan Kesehatan. 